\title{
SIMULASI PENGELOLAAN ECOFISHINGPORTDI PELABUHAN PERIKANAN SAMUDERA NIZAM ZACHMAN JAKARTA DENGAN PENDEKATAN SISTEM DINAMIK
}

\section{Ecofishingport Management Simulation at Nizam Zachman Jakarta Oceanic Fishingports Using the Dynamic System Approach}

Oleh:

\author{
Retno Muninggar ${ }^{*}$, Ernani Lubis ${ }^{1}$, Budhi Hascaryo Iskandar ${ }^{1}$, John Haluan ${ }^{1}$ \\ ${ }^{1}$ Departemen Pemanfaatan Sumberdaya Perikanan, FPIK IPB \\ "Korespondensi: rmuninggar.ipb@gmail.com
}

\begin{abstract}
ABSTRAK
Pengelolaan pelabuhan perikanan berwawasan lingkungan (ecofishingport) telah diatur dalam Kepmen KP No 6 tahun 2018 sekaligus menjadi solusi bagi permasalahan lingkungan yang terjadi di pelabuhan perikanan. Tujuan penelitian ini adalah melakukan simulasi dinamik dalam pengelolaan ecofishingport di PPS Nizam Zachman. Pendekatan case study digunakan dalam penelitian ini dengan metode analisis sistem dinamik, yaitu melakukan simulasi melalui pendekatan sub model lingkungan. Hasil penelitian menunjukkan bahwa: (1) Simulasi kebutuhan air bersih tahun 2016 adalah 2.471.585 $\mathrm{m}^{3} /$ tahun dan di tahun 2030 akan terus meningkat hingga $7.398 .327 \mathrm{~m}^{3} /$ tahun; (2) Hasil simulasi dinamik terhadap sampah menunjukkan bahwa volume Sampah Terkelola (ST) pada tahun 2016 mencapai 364.121,65 $\mathrm{m}^{3} /$ tahun, masih di bawah volume Timbulan Sampah (TS) yang sebesar 388.396,42 m³/tahun; (3) Hasil simulasi pada limbah menunjukkan bahwa Limbah Padat (LP) dan limbah Cair (LC) terus meningkat hingga tahun 2030 dan memberikan dampak pada pencemaran di pelabuhan perikanan.
\end{abstract}

Kata kunci: ecofishingport, lingkungan, Nizam Zachman, pelabuhan, perikanan

\begin{abstract}
Ecofishingport management has been regulated in the decree of the minister of maritime affairs and fisheries number 6 year 2018, it would be a solution for the environmental problems in fishingports. The objective of this research was to conduct a dynamic simulation in the ecofishingport management of PPS Nizam Zachman. The case study method was used in this research with a dynamic system analysis method using an environmental sub-model approach. The results showed that: (1) Simulation of the clean water demand in 2016 was 2,471,585 $\mathrm{m}^{3} / \mathrm{year}$ and it would be increased to 7,398,327 $\mathrm{m}^{3} /$ year in 2030; (2) Dynamic simulation results on waste showed that the volume of Managed Garbage (ST) in 2016 was 364,121.65 m3/year, it is below the volume of Disposal (TS) which has amounted to $388,396.42 \mathrm{~m}^{3} /$ year; (3) Simulation results on liquid waste showed that Solid Waste (LP) and Liquid Waste (LC) would be increased in 2030 and it would be the pollutan impact on fishingport.
\end{abstract}

Keywords: ecofishingport, environment, fisheries, Nizam Zachman, port

\section{PENDAHULUAN}

Pelabuhan berwawasan lingkungan (ecoport/greenport/ecofishingport) merupakan pelabuhan yang pengelolaannya mengikuti prinsip-prinsip pembangunan berkelanjutan yaitu keseimbangan antara dimensi sosial, ekonomi dan lingkungan (ESPO 2016; Siahaan 2012; OECD 2003; Kay dan Alder 
1999). Istilah ecofishingport telah menjadi wacana dalam pengelolaan pelabuhan perikanan sejak pemerintah Indonesia melalui Kementerian Kelautan Perikanan (KKP) melaksanakan studi kelayakan penerapan ecofishingport pada beberapa pelabuhan perikanan di Indonesia tahun 2012 (FDA dan KKP, 2013). Dasar kebijakan ecofishingport juga telah tersusun dalam Rencana Induk Pelabuhan Perikanan Nasional/RIPPN (Kepmen KP No 6 tahun 2018). Dalam RIPPN dijelaskan bahwa pengembangan pelabuhan perikanan dalam kerangka pertumbuhan ekonomi industri dilakukan melalui penerapan prinsip Pelabuhan Perikanan yang berwawasan lingkungan.

Pelabuhan Perikanan Samudera Nizam Zachman Jakarta (PPSNZJ) merupakan pelabuhan perikanan terbesar di Indonesia dan diprioritaskan untuk penerapan kebijakan pelabuhan berwawasan lingkungan (ecofishingport). Urgensitas penerapan kebijakan ecofishingport adalah melakukan pencegahan, pengurangan dan upaya mitigasi bagi dampak lingkungan yang ditimbulkan dari berbagai kegiatan di pelabuhan perikanan. PPSNJ hingga saat ini belum melaksanakan pengelolaan lingkungan secara optimal sebagaimana hasil kajian Supriyanto (2013) dan Muninggar et al(2016). Kondisi ini tentu saja akan berdampak pada kegiatan perikanan khususnya penurunan kualitas hasil tangkapan dan juga menurunnya image pelabuhan karena kurangnya sanitasi dan hygenitas. Selain itu, dampak yang lebih luas adalah menurunnya tingkat kesehatan bagi para pengguna dan masyarakat sekitar. Selain itu, limbah cair dari industri yang terdapat di PPSNJZ jika tidak dikelola dengan baik pada beberapa tahun kedepan akan menyebabkan pencemaran laut dan mengganggu keseimbangan kehidupan biota di perairan. Bahkan saat ini penurunan kualitas air di kolam pelabuhan sudah terjadi sebagaimana hasil kajian Hakim (2012) dan Muninggar et al (2017).

Penerapan konsep ecofishingport membutuhkan data untuk mengetahui bagaimana berjalannya konsep tersebut di masa depan. Upaya untuk mengetahui pengaruh variabel di dalam sistem dan perilaku dimasa yang akan datang dapat dilakukan melalui simulasi sistem dinamik. Simulasi sistem dinamik merupakan suatu metode pemecahan masalah-masalah kompleks yang timbul karena adanya kecenderungan sebab-akibat dari berbagai macam variabel didalam sistem (Firmansyah 2016). Pendekatan sistem dinamik digunakan untuk memformulasikan, mensimulasikan dan memvalidasi dengan melihat perilaku sistem dimasa yang akan datang. Proses ini memungkinkan untuk mendesain rencana kebijakan dengan baik dan dapat diimplementasikan (Widiatmaka 2014). Sistem dinamik didesain untuk analisis sistem fisik-sosial-ekonomi yang kompleks. Metode ini telah diaplikasikan pada berbagai permasalahan, termasuk untuk analisis keberlanjutan pelabuhan dan pengoperasian hinterland (Hou and Geerlings 2016); keberlanjutan industri pengolahan tuna (Fatma 2015); pengelolaan sampah (Agustia 2014); pengelolaan ekosistem terumbu karang (Chang et al. 2008; Kusumo 2012); dan reklamasi pantai (Widodo 2005).

Pendekatan sistem menggunakan simulasi yang diperlukan dalam menyelesaikan permasalahan pengelolaan pelabuhan perikanan. Adanya interaksi antar elemen didalam sistem seperti pengelolaan limbah cair, sampah, air dan pencemaran lingkungan pelabuhan. Semua nilai dari elemen tersebut dapat berubah berdasarkan waktu. Sistem dinamik dapat memberikan rekomendasi terhadap penyusunan kebijakan penerapan ecofishingport melalui skenario kebijakan. Tujuan penelitian ini adalah melakukan simulasi dinamik dalam pengelolaan ecofishingport di PPS Nizam Zachman.

\section{METODOLOGI PENELITIAN}

Penelitian dilakukan pada Januari-Maret 2017, di Pelabuhan Perikanan Samudera Nizam Zahman Jakarta (PPSNZJ), Penjaringan, Jakarta Utara, Provinsi DKI Jakarta. Penelitian menggunakan pendekatan studi kasus dengan satuan kasus adalah pengelolaan PPSNZJ dengan berbasis ecofishingport. Pengumpulan data dilakukan melalui kegiatan wawancara dan pengamatan lapang. Wawancara dilakukan kepada para responden yang dipilih secara purposive. Jumlah responden yang ditetapkan dalam kajian ini adalah 8 (delapan) orang yang terdiri dari: 1 orang Kepala PPSNZJ, 1 orang kepala bidang operasional, 2 orang staf bidang operasional serta 4 orang Staf ahli Perum Perindo (Persahaan Umum Perikanan Indonesia). Pemilihan responden dilakukan dengan pendekatan 
purposive melalui pertimbangan karakteristik sampel yang homogen dan keahlian yang dimiliki para responden.

Penelitian ini menggunakan analisis data Causal Loop Diagram dan Sub Model lingkungan. Simulasi dinamik dilakukan terhadap: (a) Kebutuhan dan suplai air bersih di PPSNZJ; (b) Produksi sampah dan pengelolaannya dan (c) Simulasi limbah padat dan cair.

Hubungan antara variabel digambarkan dalam Causal Loop Diagram yang kemudian diterjemahkan kedalam Stock Flow Diagram. Simulasi dari hasil pemodelan sistem dinamik digunakan untuk melihat pola kecenderungamnya perilaku model. Simulasi sistem dinamik merupakan suatu metode pemecahan masalah-masalah kompleks yang timbul karena adanya kecenderungan sebab akibat dari berbagai macam variabel di dalam sistem (Firmansyah 2016). Hasil simulasi model dianalisis pola dan kecenderungannya, ditelusuri faktor-faktor yang menyebabkan terjadinya pola dan kecenderungan tersebut, serta dijelaskan bagaimana mekanisme kejadian berdasarkan analisis struktur model. Tahap formulasi model simulasi dijalankan menggunakan software program Powersim Studio 10.

\section{HASIL DAN PEMBAHASAN}

\section{Diagram lingkar sebab akibat (causal loop diagram)}

Diagram lingkar sebab akibat terdiri dari variabel-variabel yang dihubungkan oleh tanda panah yang menunjukkan pengaruh sebab akibat diantara variabel-variabel tersebut. Diagram lingkar sebabakibat (Gambar 1), menunjukkan bahwa optimalisasi pengelolaan pelabuhan perikanan berbasis ecofishingport melalui peningkatan pengelolaan limbah cair dan sampah akan menurunkan tingkat pencemaran di pelabuhan perikanan, dan semakin tingginya penyediaan air bersih maka akan memberikan kelancaran pada kegiatan industri, kapal perikanan dan pengguna pelabuhan lainnya. Selain itu dengan adanya industri perikanan di PPSNZJ akan meningkatkan limbah cair sebagai dampak negatif.

Keberadaan limbah cair dapat diminimalisir dengan adanya pengelolaan limbah. Air hasil olahan dapat dengan aman dibuang ke laut, dan air laut yang bersih bila diolah di fasilitas Sea Water Reverse Osmosis ( $S W R O$ ) akan menghasilkan air yang dapat digunakan untuk mendukung kegiatan operasional pelabuhan seperti kegiatan membersihkan kapal, TPI, MCK, dan sebagainya kecuali untuk air minum.

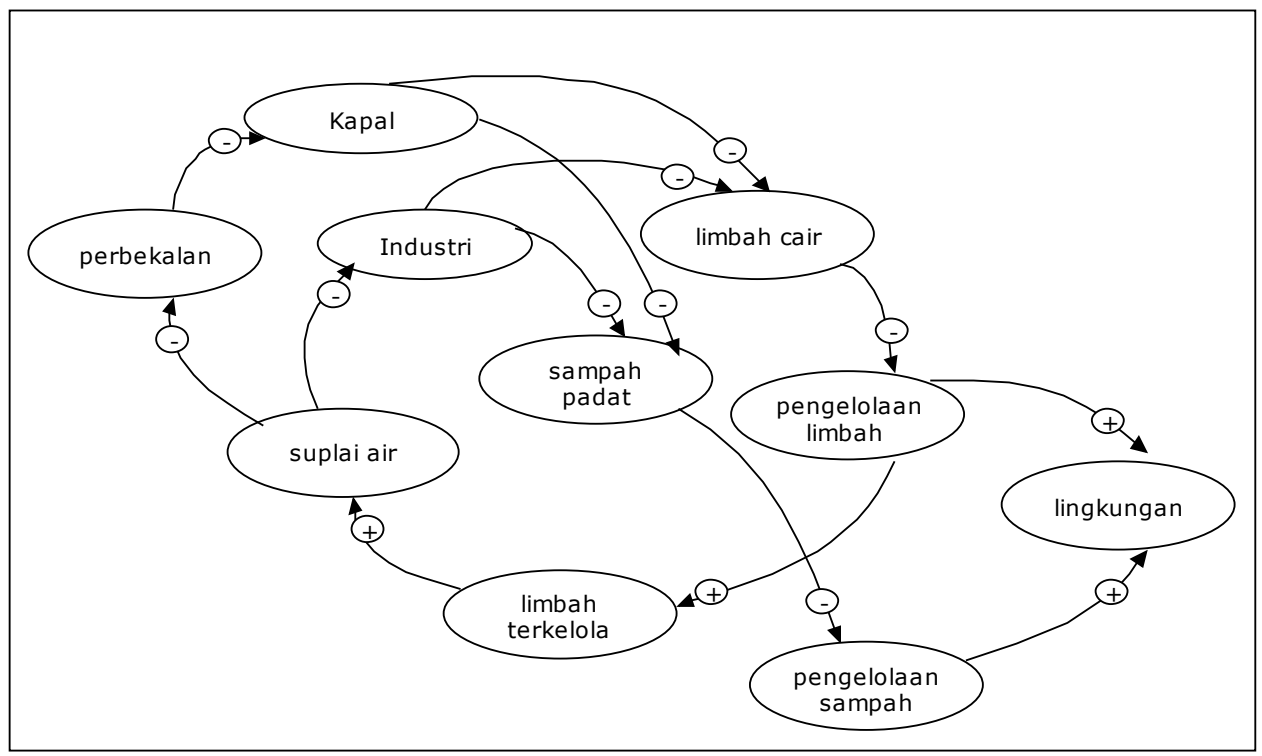

Gambar 1 Diagram lingkar sebab akibat (causal loop diagram) 


\section{Sub model lingkungan}

Lingkungan sebagai suatu sistem terdiri atas variabel-variabel pembentuknya. Jika pada elemen ini terjadi suatu perubahan, maka perubahan tersebut akan mempengaruhi sistem itu sendiri. Kondisi ini dapat terlihat pada sub model lingkungan (Gambar 2) yang memperlihatkan bahwa suplai air sebagai laju masukan pada level ketersediaan air. Suplai air merupakan perkalian antara fraksi pengguna dengan perusahaan (penyedia air bersih) dengan fraksi pengguna pelabuhan sebagai konstanta.

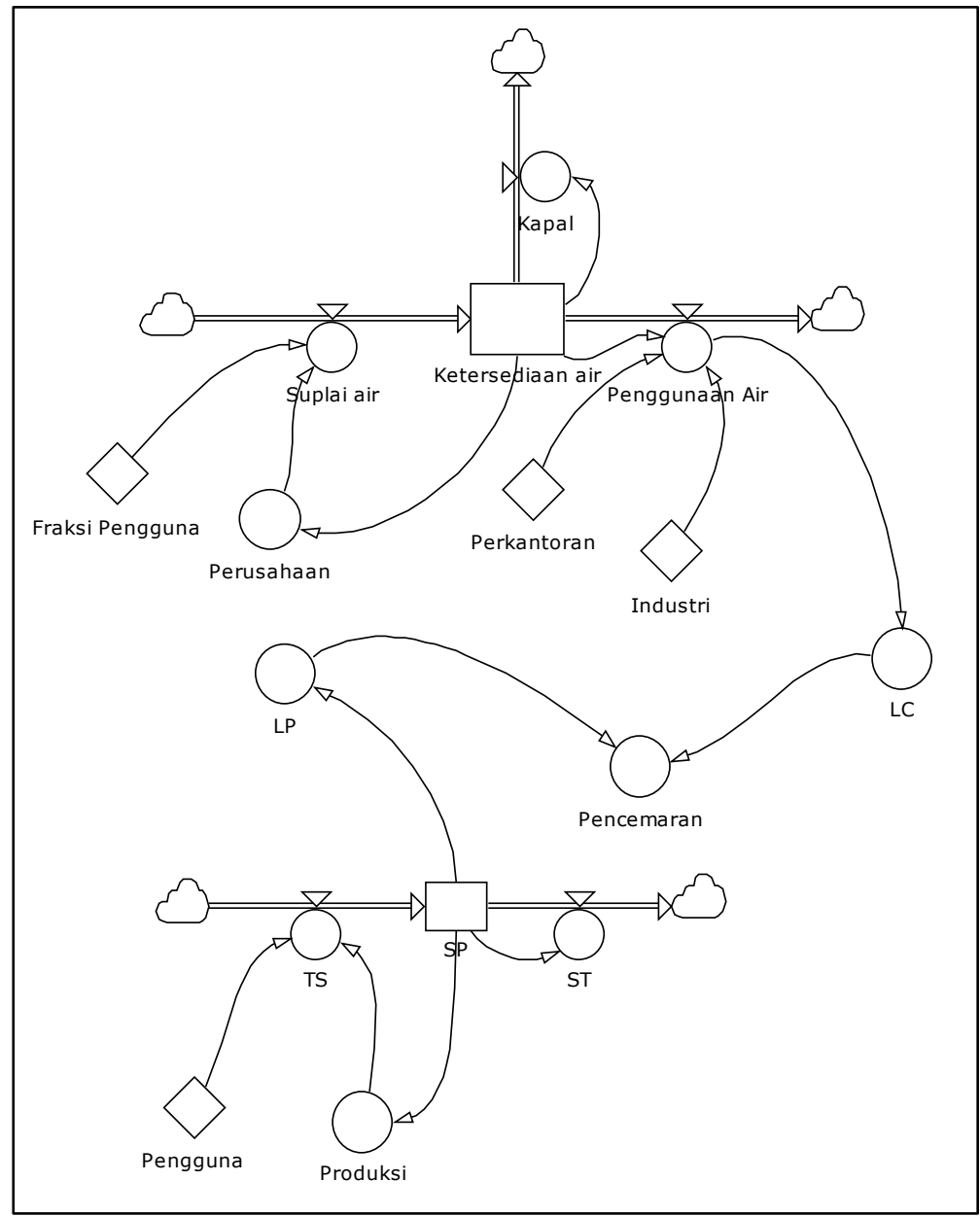

Gambar 2 Flow diagram simulasi model lingkungan

Tabel 1. Persamaan yang berkaitan dengan model lingkungan

\begin{tabular}{lcl}
\hline \multicolumn{1}{c}{ Nama Variabel } & Satuan & \multicolumn{1}{c}{ Keterangan } \\
\hline Fraksi pengguna & $\%$ & 'pertumbuhan jumlah pengguna' \\
Suplai air & $\mathrm{m}^{3} /$ tahun & 'Fraksi Pengguna'*Perusahaan' \\
Penggunaan air & $\mathrm{m}^{3} /$ tahun & $0.6^{*}$ (Industri+Perkantoran)*'Kebutuhan air' \\
Perusahaan & $\mathrm{m}^{3} /$ tahun & '0.74*'Kebutuhan air' \\
LC (Limbah Cair) & $\mathrm{m}^{3} /$ tahun & '0.6*'Penggunaan lain' \\
& & \\
SP (Sampah Padat) & $\mathrm{m}^{3} /$ tahun & 485495.53 (estimasi sampah pengguna PP) \\
Produksi & $\mathrm{m}^{3} /$ tahun & Pengguna* TS \\
ST (Sampah Terkelola & $\mathrm{m}^{3} /$ tahun & $0.75^{*} \mathrm{SP}$ \\
TS (Timbulan Sampah) & $\mathrm{m}^{3} /$ tahun & $0.8^{*} \mathrm{SP}$ \\
Pencemaran & & LC (Limbah cair) + LP (Limbah Padat) \\
\hline
\end{tabular}

Sumber: data primer yang telah diolah (2017) 


\section{Simulasi diamik kebutuhan dan suplai air bersih}

Simulasi suplai air bersih (Gambar 3) menunjukkan bahwa tahun 2016 kebutuhan air bersih adalah 2.471.585 m³/tahun dan di tahun 2030 akan terus meningkat hingga $7.398 .327 \mathrm{~m}^{3} /$ tahun. Kebutuhan air ditunjukkan pada simulasi peningkatan kebutuhan air untuk kapal dan pengguna lain. Dengan adanya peningkatan kebutuhan air, maka suplai air juga harus terus ditingkatkan. Tahun 2016 suplai air dari 4 (empat) perusahaan penyedia air bersih baru mampu memenuhi kebutuhan sebanyak $1.679 .000 \mathrm{~m}^{3} /$ tahun atau hanya $73 \%$ dari data estimasi kebutuhan air di PPSNZJ (Tabel 2). Upaya pemenuhan kebutuhan air bersih dapat dilakukan melalui peningkatan penggunaan teknologi SWRO. Pengolahan air bersih di PPSNZJ dilakukan dengan teknologi membran Reverse Osmosis (osmosis terbalik) digunakan untuk desalinasi (mengolah air asin menjadi tawar), dan juga mengolah air limbah atau air kotor menjadi air bersih. Reverse Osmosis/RO (telah banyak dipakai di beberapa negara seperti Amerika, Jepang, Jerman, Arab, Australia juga di Indonesia. Teknologi RO di PPSNZJ dimanfaatkan untuk mendapatkan air bersih guna memenuhi kebutuhan air di pelabuhan. Suplai air bersih dengan teknologi RO di PPSNZJ di penuhi dari tiga perusahaan penyedia air bersih (PT TSA, CNE dan SBU) selain itu ada juga air bersih yang berasal dari PT Palyja. PT TSA berada di bawah pengelolaan UPT PPSNZJ, sedangkan yang lainnya di bawah pengelolaan Perum Perindo. Suplai air bersih di PPSNZJ ditujukan untuk memenuhi kebutuhan perbekalan air bersih bagi kapal-kapal perikanan yang akan melaut. Setiap harinya sekitar 300-400 unit kapal bertambat di PPSNZJ. Dari jumlah tersebut, sebanyak 100 kapal keluar masuk dan memerlukan bekal air bersih untuk kembali melaut. Kebutuhan air bersih kapal-kapal tersebut mencapai $6.000 \mathrm{~m}^{3}$ perhari. Suplai air bersih juga digunakan oleh pengusaha perikanan dan pengguna pelabuhan lainnya.

Selain itu, suplai air bersih masih dikeluhkan oleh sebagian pengusaha industri Tuna karena air yang dipasok kurang bersih dan akhirnya harus mensuplai air dari luar pelabuhan (Hutapea 2017). Terkait kualitas air, pengujian sampel air tawar olahan dilakukan setiap 3 (tiga) bulan sekali, bekerjasama dengan Dinas Lingkungan Hidup Daerah Provinsi DKI Jakarta dan fasilitas SWRO.

Tabel 2 Estimasi perhitungan kebutuhan air bersih di PPSNZJ

\begin{tabular}{lrl}
\hline \multicolumn{1}{c}{ Jenis penggunaan air } & Volume $\left(\mathrm{m}^{3}\right)$ & \multicolumn{1}{c}{ Sumber data } \\
\hline Perbekalan kapal melaut & 438.689 & Statistik PPSNZJ (2017) \\
Industri & 865.190 & $\begin{array}{l}\text { Hasil perhitungan : 36.58 ha x 0.75 } \\
\text { liter/detik }\end{array}$ \\
Pegawai dan pengguna & 967.706 & $\begin{array}{l}\text { Hasil perhitungan : 53025 orang x } \\
\text { 50liter/hari }\end{array}$ \\
& & \\
Total kebutuhan air & 2.271 .585 & \\
Suplai air & 1679000 & $4600 \mathrm{~m}^{3} \times$ 365hari \\
\hline Defisit & 592586 & \\
\hline
\end{tabular}

Sumber : data primer yang telah diolah (2017)

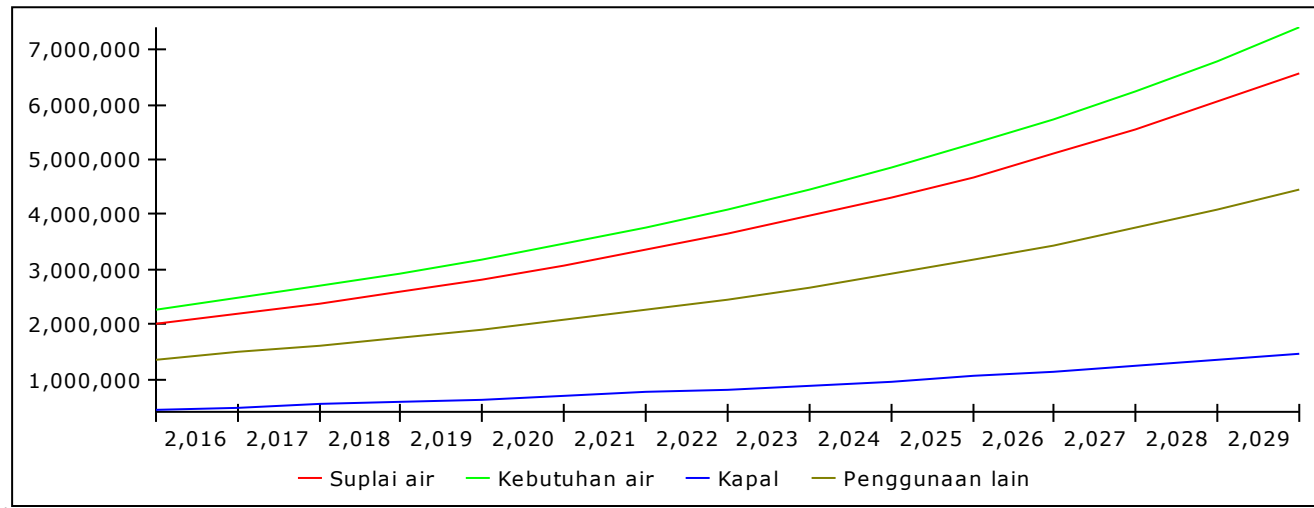

Gambar 3 Simulasi kebutuhan dan suplai air bersih dan di PPSNZJ 


\section{Simulasi dinamk produksi sampah dan pengelolaannya}

Hasil simulasi dinamik pada produksi sampah di PPSNZJ pada tahun 2016 mencapai 504.915,35 $\mathrm{m}^{3} /$ tahun (Gambar 4). Nilai produksi sampah diestimasi melalui perhitungan volume sampah perorang yaitu 25 liter/hari (sumber) dikalikan jumlah pengguna PPSNZJ. Data jumlah pengguna diasumsikan sama dengan jumlah tenaga kerja nelayan dan non nelayan tahun 2016 yaitu 53.205 orang. Volume Sampah Terkelola (ST) pada tahun 2016 mencapai 364.121,65 m³/tahun, masih di bawah volume Timbulan Sampah (TS) yang sebesar 388.396,42 $\mathrm{m}^{3} /$ tahun, karena itu dibutuhkan upaya yang serius dalam pengelolaan sampah melalui program 3R (Reduce, Reuse, Recycle).

Program penanganan sampah padat di PPSNZJ dilakukan melalui pengumpulan sampah dari semua kawasan/zonasi, kemudian diangkut dengan thowing truck dan dikumpulkan di dump truck untuk diangkut keluar pelabuhan, sebagian sampah juga dibakar dengan incinerator. Upaya pemulihan dampak belum dilaksanakan oleh pelabuhan. Upaya pemulihan dampak akibat sampah dapat dilakukan melalui pengolahan sampah atau limbah (re-used) menjadi sumberdaya alam yang dapat dimanfaatkan kembali (new resource) sehingga efisiensi pemanfaatan sumberdaya alam dapat dilakukan, atau yang dikenal dengan ecoefficiency (Fandeli 2012).

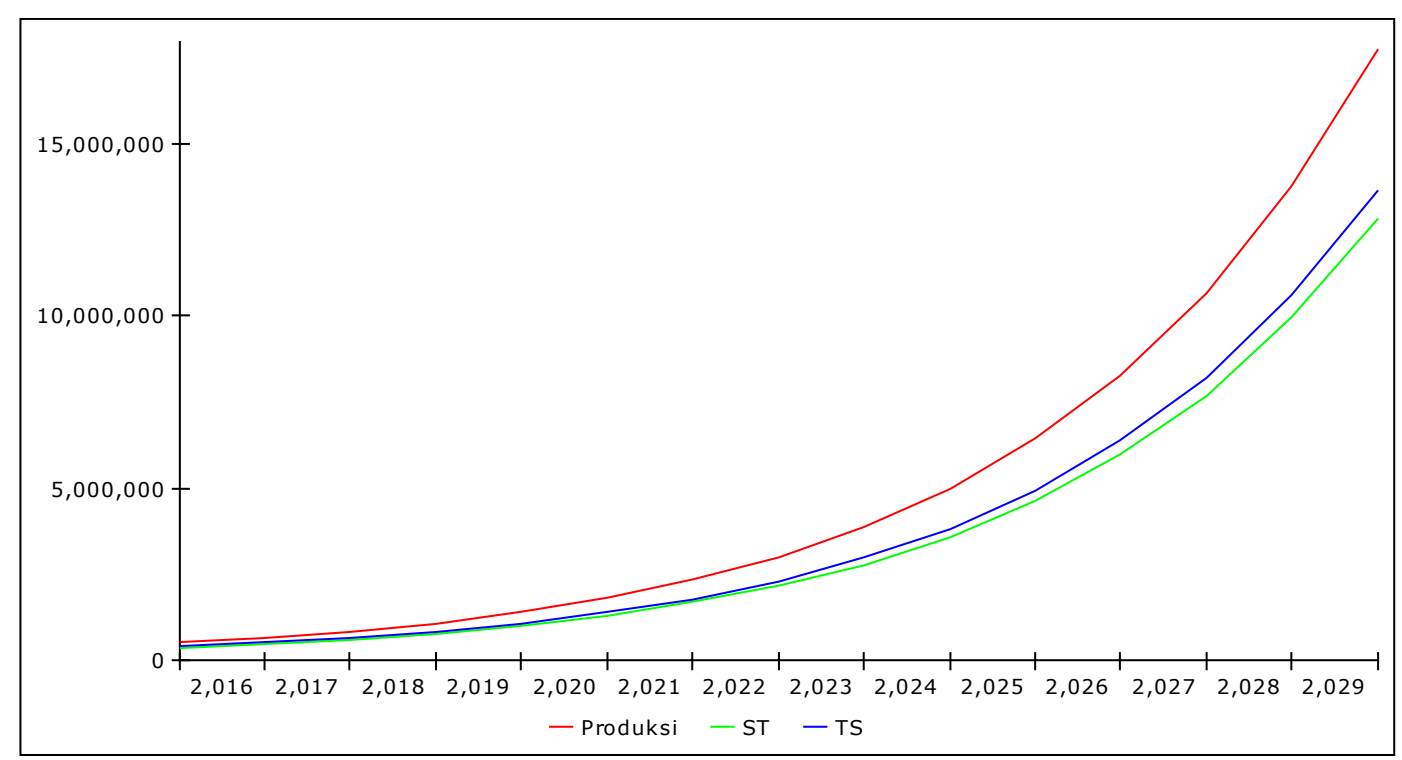

Gambar 4 Simulasi produksi sampah dan pengelolaannya

\section{Simulasi dinamik untuk limbah padat dan cair}

Hasil simulasi pada Gambar 5 menunjukkan bahwa Limbah Padat (LP) dan limbah Cair (LC) terus meningkat hingga tahun 2030 dan memberikan dampak pada pencemaran di pelabuhan perikanan. Limbah cair terus meningkat meski angkanya masih dibawah Limbah Padat. Kondisi tersebut dikarenakan adanya IPAL (Instalasi Pengolahan Air Limbah) yang mengolah limbah cair menjadi air yang bersih. Upaya mengurangi limbah cair dengan melakukan pemeliharaan IPAL.

Kegiatan pengelolaan limbah cair telah didukung upaya pemantauan terhadap kualitas buangan limbah dari fasilitas IPAL. Pemantauan dilakukan oleh pihak PPSNZJ bekerjasama dengan Badan Pengelola Lingkungan Hidup Daerah/BPLHD Provinsi DKI Jakarta melalui uji kualitas air limbah pada fasilitas IPAL. Pihak Pemda DKI telah mengatur baku mutu air limbah untuk kegiatan/usaha industri pengolahan ikan dalam Peraturan Gubernur DKI Jakarta No 69 Tahun 2013.

Data BPLHD terhadap hasil pengujian air limbah olahan pada fasilitas IPAL menunjukkan bahwa pada tahun 2015-2017 sejumlah parameter (TSS, Ammonia, BOD, COD dan Organik) berada di atas baku mutu air limbah (BPLHD Propinsi DKI Jakarta 2015;2016;2017). Hal ini disebabkan oleh faktor mesin dan peralatan yang butuh perawatan, kemampuan SDM serta proses IPAL itu sendiri 
(Perdana 2017). Kondisi tersebut mengharuskan perbaikan pada mesin IPAL milik PPSNZJ. Parameter yang berada diatas baku mutu harus diperhatikan oleh pihak PPSNZJ karena dapat saja menjadi alasan bagi LSM untuk menuntut PPSNZJ terkait pembuangan limbah ke badan air.

Fasilitas IPAL yang dibangun pada tahun 2001, pada awalnya memiliki kapasitas $1000 \mathrm{~m}^{3} /$ hari, saat ini kapasitasnya hanya sekitar $800 \mathrm{~m}^{3} /$ hari. Hal ini senada dengan hasil kajian Perdana (2017) yang menyebutkan bahwa kapasitas IPAL PPSNZJ hanya sekitar 85\%. Bahan organik seperti BOD, COD, $T S S$ dan lemak merupakan bahan organik yang terdapat pada limbah industri perikanan. Bahan organik tersebut jika dibuang ke badan penerima maka akan terjadi pencemaran air pada badan air.

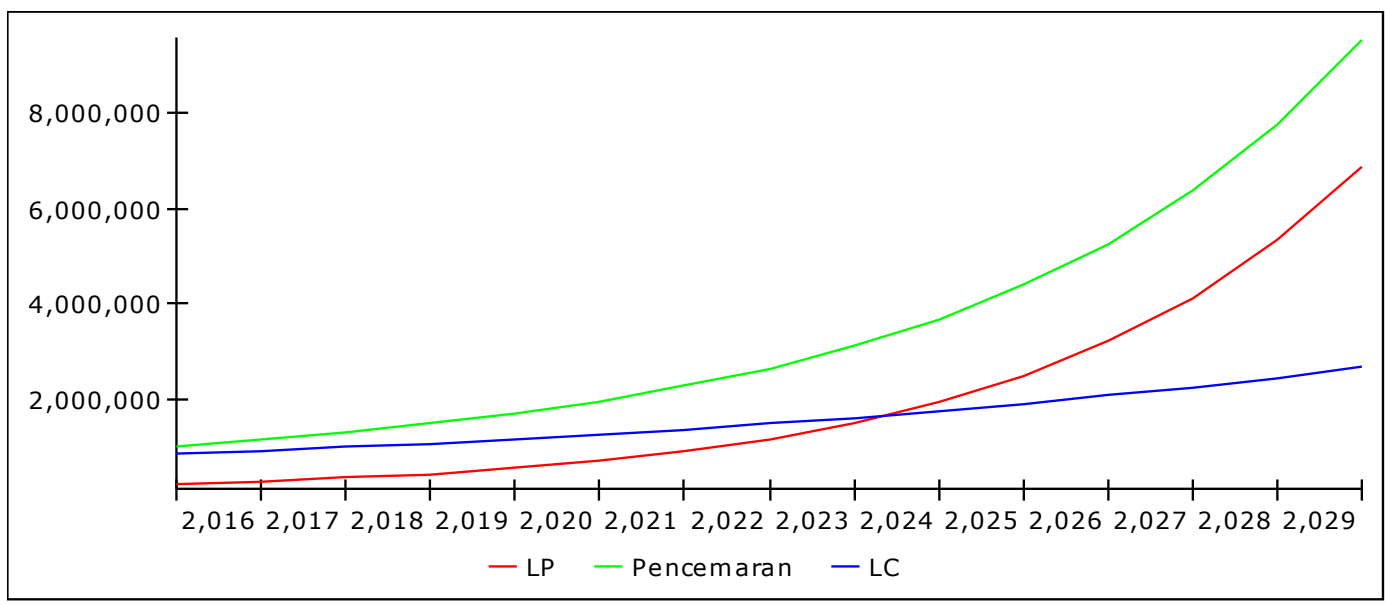

Gambar 5 Simulasi limbah padat dan cair yang menyebabkan pencemaran lingkungan

\section{KESIMPULAN DAN SARAN}

Simulasi dinamik pada sub model lingkungan yang dilakukan dalam pengelolaan ecofishingport di PPSNZJ mneghasilkan kesimpulan sebagai berikut: (1) Simulasi kebutuhan air bersih tahun 2016 adalah $2.471 .585 \mathrm{~m}^{3} /$ tahun dan di tahun 2030 akan terus meningkat hingga $7.398 .327 \mathrm{~m}^{3} /$ tahun, penyediaan air bersih di PPSNZJ baru dapat memenuhi sebanyak 73\% kebutuhan air bersih; (2) Hasil simulasi dinamik terhadap sampah menunjukkan bahwa volume Sampah Terkelola (ST) pada tahun 2016 mencapai 364.121,65 m³/tahun, masih di bawah volume Timbulan Sampah (TS) yang sebesar 388.396,42 m³/tahun, hal ini menunjukkan bahwa upaya pengelolaan sampah belum optimal; (3) Hasil simulasi pada limbah menunjukkan bahwa Limbah Padat (LP) dan limbah Cair (LC) terus meningkat hingga tahun 2030 dan memberikan dampak pada pencemaran di pelabuhan perikanan.

Saran dari penelitian ini adalah perlu adanya kajian strategi pengelolaan untuk mengantisipasi hasil simulasi pada beberapa aspek lingkungan seperti ketersediaan air bersih yang masih di bawah kebutuhannya, volume timbunan sampah yang belum terkelola dan peningkatan pengelolaan limbah cair melalui perbaikan sarana IPAL.

\section{DAFTAR PUSTAKA}

Agustia YP. Model sistem dinamik pada pengembangan pengelolaan sampah Kecamatan Gubeng, Kota Surabaya [tesis]. Surabaya (ID): Institut Teknologi Sepuluh November.

[BPLHD] Badan Pengelola Lingkungan Hidup Daerah DKI Jakarta. 2015. Hasil Pengujian Kualitas Air pada Fasilitas Instalasi Pengolahan Limbah (IPAL) PPS Nizam Zachman periode 2015-2017. Jakarta (ID). BPLHD. 
[BPLHD] Badan Pengelola Lingkungan Hidup Daerah DKI Jakarta. 2016. Hasil Pengujian Kualitas Air pada Fasilitas Instalasi Pengolahan Limbah (IPAL) PPS Nizam Zachman periode 2015-2017. Jakarta (ID). BPLHD.

[BPLHD] Badan Pengelola Lingkungan Hidup Daerah DKI Jakarta. 2017. Hasil Pengujian Kualitas Air pada Fasilitas Instalasi Pengolahan Limbah (IPAL) PPS Nizam Zachman periode 2015-2017. Jakarta (ID). BPLHD.

Chang YC, Hong FW, Lee MT. 2008. A system dynamic based DSS for sustainable coral reef. Ecological Modelling. 211:153-168.

[ESPO] European Sea Port Organization. 2016. EcoPorts Port Environmental Review 2016 [internet]. [diacu 2017 Agustus 8]. Tersedia dari http://www.espo.com.

[FDA dan KKP] French Development Agencydan Kementerian Kelautan dan Perikanan. 2013. Fishing EcoPorts Preliminary Report. Implementation And Follow-Up Mission To Promote The Identification And Structuring Of Renewable Energy And Energy Efficiency Investments In Indonesia Preliminary report-concept of fishing ecoports - (Padang, Bitung, Jakarta, Pelabuan Ratu, Cilacap, Kendari) in Indonesia. Jakarta (ID): KKP.

Fatma E. 2015. Development of sustainable tuna processing industry using system dynamics simulation. Procedia Manufacturing. 4:107-114.

Fandeli C. 2012. Analisis Mengenai Dampak Lingkungan. Jogjakarta (ID). Gadjah Mada University Press.

Firmansah I. 2016. Model Pengendalian Konversi Lahan Sawah di Dalam DAS Citarum [disertasi]. Bogor (ID). Institut Pertanian Bogor.

Hakim LN. 2013. Pengelolaan Kualitas Lingkungan Perairan Pelabuhan Perikanan Samudera Nizam Zachman Jakarta [tesis]. Depok (ID): Universitas Indonesia. 95 hal.

Hou L, Geerlings H. 2016. Dynamics in sustainable port and hinterland operations: A conceptual framework and simulation of sustainability measures and their effectiveness, based on an application to the Port of Shanghai. Journal of Cleaner Production. 135:449-456.

Hutapea RYF. 2017. Peran Pelabuhan Perikanan Samudera Nizam Zachman Jakarta Dalam Mendukung Industri Perikanan Tuna [tesis]. Bogor (ID): Institut Pertanian Bogor. 77 hal.

Kay R, Alder J. 1999. Coastal Planning and Management. Second Edition. Taylor \& Francis. 341 hal.

Kusumo S. 2012. Model dinamik pengelolaan ekosistem terumbu karang di Pulau Pramuka, Taman Nasional Kepulauan Seribu [tesis]. Bogor (ID): Institut Pertanian Bogor.

[KKP] Kementerian Kelautan dan Perikanan. 2018. Keputusan Menteri Kelautan dan Perikanan Nomor 6 Tahun 2018 tentang Rencana Induk Pelabuhan Perikanan Nasional. Jakarta (ID): KKP.

Muninggar R, Lubis E, Iskandar BH, Haluan J. 2017. Water quality status in the largest Indonesian fishingport. Advance Environmental Sciences Bioflux. 9(3):173-182.

Muninggar R, Lubis E, Iskandar BH, Haluan J. 2016. Aspek lingkungan signifikan di Pelabuhan Perikanan Samudera Nizam Zachman Jakarta. Marine Fisheries. 7(2):203-210.

[OECD] Organization for Economic Co-Operation and Development. 2008. OECD Environemntal Indicators. Development, Measurement and Use. 37 hal.

Perdana, D. 2017. Analisis dan Mitigasi Risiko Terhadap Kinerja IPAL Pelabuhan Perikanan menggunakan Metode Fault Tree Analysis (FTA) [tesis]. Surabaya (ID). Institut Teknologi Sepuluh November.189 hal. 
Siahaan EI. 2012. Pengembangan Pelabuhan Berwawasan Lingkungan (Ecoport) Dalam Rangka Pengelolaan Pesisir Terpadu (Studi Kasus Pelabuhan Tanjung Priok) [disertasi]. Bogor (ID): Institut Pertanian Bogor: 249 hal.

Supriyanto. 2013. Analisis pengelolaan pelabuhan perikanan berwawasan lingkungan di Pelabuhan Perikanan Samudera Nizam Zachman Jakarta. Jurnal Ilmu Lingkungan. 7(2):160-179.

Widiatmaka, Ambarwulan W, Firmansyah I, Munibah K, Santoso PBK, Sudarsono. 2014. Land Suitability and Dynamic System Modelling To Define Priority Araes Of Soybean Plantation In Paddy Fields In Karawang, West Java. Agrivita. 36(3):235-248.

Widodo L. 2005. Kecenderungan reklamasi wilayah pantai dengan pendekatan model dinamik. Jurnal Teknologi Lingkungan. P3TL-BPPT. 6(1):330-338. 